\title{
IMPLEMENTASI MODEL PBI DISERTAI MEDIA VIRTUAL LABORATORY PADA POKOK BAHASAN GERAK LURUS SEBAGAI UPAYA MENINGKATKAN KETERAMPILAN PROSES SAINS SISWA SMA
}

\author{
${ }^{1)}$ Dini Febrianti, ${ }^{1)}$ Lailatul Nuraini ${ }^{1)}$ Bambang Supriadi, ${ }^{2}$ Syaihun Atiq L.R \\ ${ }^{1)}$ Program Studi Pendidikan Fisika FKIP Universitas Jember \\ ${ }^{2)}$ SMA Muhammadiyah 3 Jember \\ Email: Dinifebrianti1702@gmail.com
}

\begin{abstract}
This research aimed to: 1) analyzing the comparison of the process of student learning activities with research methods with the PBI (Problem Based Instruction) model in 2 classes each class will try a different learning system: (1) X IPA 1 using the direct instruction method, namely the teacher provides material explanations to students. (2) $X$ IPA 2 using a virtual laboratory system, namely by practicing using Phet Simulation. 2) analyzing which learning system is being tried more effectively on students, which will later be used for the learning system to be more effective in the learning process. Method of this research was experimental research. The data collection technique used pre-test and posttest given to students. Analysis of data collection is that the pre-test scores of students in class X IPA 1 and IPA 2 are taken the average as a reference value for comparison. After being given learning using different media, students were given a post-test and the average was taken, then analyzed. The highest mean increase from pre-test to post-test. The results showed that the virtual system using Phet Simulation in class X IPA 2 had better results than direct instruction method in class X IPA 1.

Keywords: problem based instruction, virtual laboratory, physics learning.
\end{abstract}

\section{PENDAHULUAN}

Proses pembelajaran merupakan salah satu faktor utama dalam mencapai tujuan pembelajaran, tentunya banyak faktor yang mepengaruhi salah satunya adalah guru. Guru berperan sebagai pengatur jalannya suatu pembelajaran di kelas. Kurikulum 2013 mengharuskan pembelajaran yang menitikberatkan pada keaktifan siswa. Pada kenyataannya pembelajaran di sekolah masih menitikberatkan pada guru, dengan kata lain kurikulum 2013 belum sepenuhnya diterapkan di sekolah-sekolah. Permasalahan ini dijumpai di SMA Muhamadiyah 3 Jember, penerapan kurikulum 2013 belum sepenuhnya dilaksanakan dengan baik. Pembelajaran di kelas masih terpusat pada guru. Hal ini bertolak belakang dengan tujuan dari kurikulum 2013, salah satunya yaitu pembelajaran terpusat pada siswa.

Materi fisika adalah mata pelajaran yang membutuhkan pemahaman tentang konsep, maka perlu adanya seorang guru yang mampu menguasai materi dan mentransferkan ilmu kepada peserta didik. metode yang sering digunakan guru dalam memberikan materi fisika kepada peserta didik adalah metode konvensional atau ceramah. Metode ceramah banyak digunakan guru karena beberapa alasan, salah satunya yaitu karena materi yang disampaikan 
relatif banyak sedangkan waktu untuk menyampaikan materi itu sendiri terbatas. Dengan metode ceramah, guru dapat menyampaikan informasi dalam jumlah banyak dengan waktu singkat. Tuntutan materi pelajaran yang banyak membuat guru kurang berinovasi dalam kegiatan pembelajaran. Meskipun memiliki kelebihan tersebut, namun metode ceramah memiliki kekurangan dimana komunikasi yang terjadi hanya satu arah, pembelajaran hanya berpusat pada guru. Metode kovensional yang sering digunakan pada proses pembelajaran membuat peserta didik menjadi pasif dan di sekolah banyak dijumpai peserta didik yang mengeluhkan pelajaran fisika membosankan.

Salah satu langkah yang dapat menjadi solusi adalah menggunakan model pembelajaran yang melibatkan siswa secara langsung yaitu Problem Based Instruction (PBI) atau pembelajaran berdasarkan masalah (PBM) adalah suatu model pembelajaran yang menggunakan masalah sebagai langkah awal dalam mengumpulkan dan mengembangkan pengetahuan baru bagi siswa melalui proses kerja kelompok yang membutuhkan penyelesaian nyata sehingga membuat siswa berpartisipasi aktif dalam kegiatan pembelajaran.

Model pembelajaran berbasis masalah (PBI) berpusat pada kegiatan siswa. Dalam proses pembelajaran, guru bertindak sebagai fasilitator sedangkan siswa yang dituntut untuk lebih aktif dalam bertanya, menjawab, berpendapat, menyanggah pendapat, dan sebagainya. Pembelajaran berdasarkan masalah merupakan pendekatan yang efektif untuk pengajaran proses berpikir tingkat tinggi. Pembelajaran ini membantu siswa untuk memproses informasi yang sudah jadi dalam benaknya dan menyusun pengetahuan mereka sendiri tentang dunia sosial dan sekitarnya.

Dalam proses belajar mengajar guru dituntut harus memiliki kreatifitas yang tinggi dalam penyajian materi pelajaran. Pemberian pembelajaran di sekolah yang dilakukan oleh guru dengan cara-cara tertentu dapat menumbuhkan motivasi belajar, peserta didik yang termotivasi akan dengan mudah diarahkan, diberi penugasan, cenderung memiliki rasa ingin tahu yang besar, aktif dalam mencari informasi tentang materi yang dijelaskan oleh guru dan cepat menyerap pelajaran yang diberikan.

Seiring perkembangan teknologi telah tersedia berbagai fasilitas untuk penunjang proses pembelajaran. Salah satunya dengan menggunakan aplikasi Program berbasis Virtual Laboratory PhET (Physics Education Technology), yang menyediakan simulasi fenomena fisik berbasis penelitian secara gratis, menyenangkan, interaktif dan bias mengajak siswa untuk belajar dengan cara-cara mengeksplorasi secara langsung. Dengan program ini, siswa bisa lebih nyata mengamati fenomena yang ada sehingga bias menumbuhkan motivasi lebih tinggi untuk belajar.

Berdasarkan uraian di atas, maka diperlukan upaya untuk melihat perbandingan hasil belajar siswa yang diajarkan dengan menggunakan virtual praktek PhET simulation dan sistem konvensional atau ceramah dengan metode PBI (Problem Based Instruction). Penelitian ini bertujuan untuk mengetahui perbandingan keterampilan proses sains siswa yang diajarkan menggunakan virtual 
laboratory dengan PhET simulation dan sistem metode ceramah dengan model PBI (Problem Based Instruction) di SMA Muhamadiyah 3 Jember

\section{METODE PENELITIAN}

Jenis penelitian ini adalah penelitian eksperimen yang mendalami suatu kelompok siswa. Hasil penelitian berlaku terbatas pada siswa yang diteliti saja dan kesimpulan yang diambil tidak dapat digeneralisasikan pada keahlian di luar kasus yang diteliti. Subjek penelitian ini adalah peserta didik kelas X SMAS Muhammadiyah 3 Jember. Jumlah subjek penelitian uji coba terbatas (konvensional) yaitu 30 peserta didik kelas X IPA 1. Jumlah subjek penelitian pada uji lapangan (virtual) yaitu 30 peserta didik kelas X IPA 2.

Metode pengumpulan data dengan memberikan pre-test terlebih dahulu sebagai acuan penelitian, lalu dilaksanakan pembelajaran dengan menggunakan media yang berbeda. Untuk X IPA 1 menggunakan Problem Based Instruction dengan metode ceramah yang berpusat pada guru, sedangkan $\mathrm{X}$ IPA 2 menggunakan Problem Based Instruction dengan media PhET Simulation sebagai virtual laboratory siswa. Setelah pembelajaran selesai, siswa diberi soal post-test untuk pembanding, peningkatan ratarata mana yang paling besar dalam pembelajaan gerak lurus dengan menggunakan media dan metode yang berbeda. Teknik analisis data setiap kelas di hitung rata-rata pre-testnya, setalah itu dilaksanakan penelitian dangan menggunakan media dan metode yang berbeda. Pemberian postest kepada siswa, lalu dihitung rata- ratanya, dan dibandingkan. Peningkatan dari pre-test ke post-test yang paling besar yang media konvensional atau media virtual laboratory. Pada penelitian ini dilakukan dengan 3 tahap, yakni :

1. Tahap Pendefinisian : Pada tahap pedefinisian terdapat analisis awal, analisis peserta didik, analisis konsep dan persiapan perangkat. Untuk analisis awal, analisis peserta didik dan analisis konsep, peneliti harus observasi dahulu mengenai sekolah, keadaan peserta didik memiliki laptop atau tidak,bagaimana cara mengajar guru, dan sampai sejauh mana pemahaman siswa. Dilanjutkan dengan persiapan perangkat dengan menyusun sol pre-test dan post-test untuk siswa dan tidak lupa menyiapkan aplikasi PhET Simulation

2. Tahap Perancangan : Pada tahap perancangan, peneliti mempersiapkan aplikasi PhET Simulation sebagai virtual laboratory dan memili sub pokok mengenai Gerak Lurus Beraturan dan Gerak Lurus Berubah Beraturan, yaitu The Moving Man.

3. Tahap Eksperimen : Pada tahap pengembangan dibagi menjadi 2 , yakni uji terbatas dan uji lapangan. Uji terbatas, ialah penelitian yang dilakukan dengan metode ceramah tanpa menggunkakan media, perlakuan yang diberikan ke X IPA 1. Sedangkan uji lapangan (eksperimen) ialah penelitian yang menggunakan model virtual laboratory (PhET Simulation), perlakuan yang diberikan kepada $\mathrm{X}$ IPA 2. Langkah penelitian ini secara ringkas dapat dilihat pada Gambar 1 berikut. 


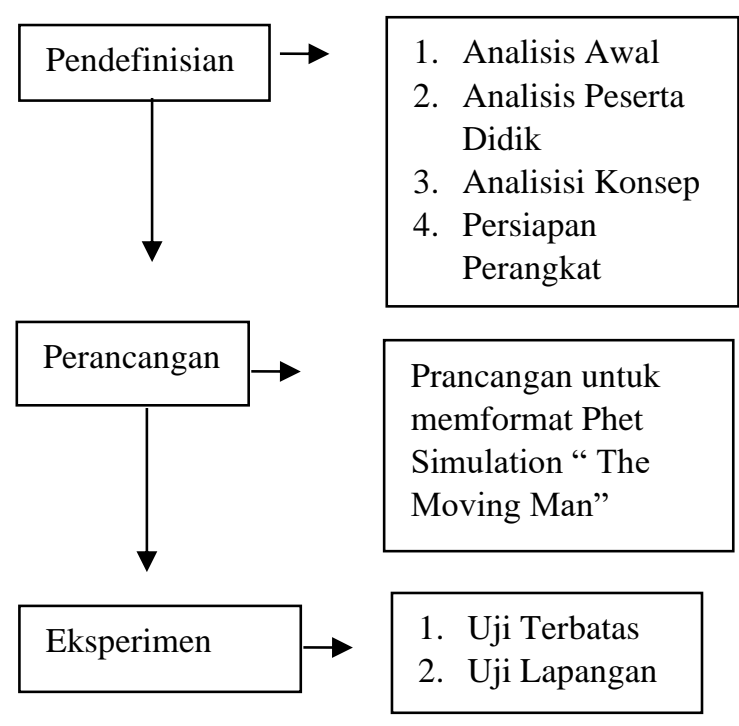

Gambar 1. Design tahapan penelitian secara singkat

\section{HASIL DAN PEMBAHASAN}

Setelah pembelajaran selesai baik mengunakan metode ceramah (X IPA 1) dan media virtual PhET Simulation (X IPA 2), siswa diberi pesoalan atau pos-test untuk mengukur sejauh mana siswa dapat berfikir pada keterampilan bidang sains, Post-test yang diberikan sebanyak 10 soal (5 soal tentang Gerak Lurus Beraturan (GLB) dan 5 soal lagi tentang gerak lurus berubah beraturan (GLBB). Posttest dilakukan di kelas X IPA 1 dan $\mathrm{X}$ IPA 2. Berikut ialah Tabel 1 menunjukkan hasil penelitian untuk teknik analisis data

Tabel 1. Tabel hasil penelitian

\begin{tabular}{|l|l|c|c|c|}
\hline Kelas & Metode & Pretest & Postest & $\begin{array}{c}\text { Peningkatan } \\
\text { (posttest-pretest) }\end{array}$ \\
\hline X IPA 1 & Ceramah & 82,56 & 70,93 & $-11,63$ \\
\hline X IPA 2 & PhET & 87 & 88,9 & 1,9 \\
\hline
\end{tabular}




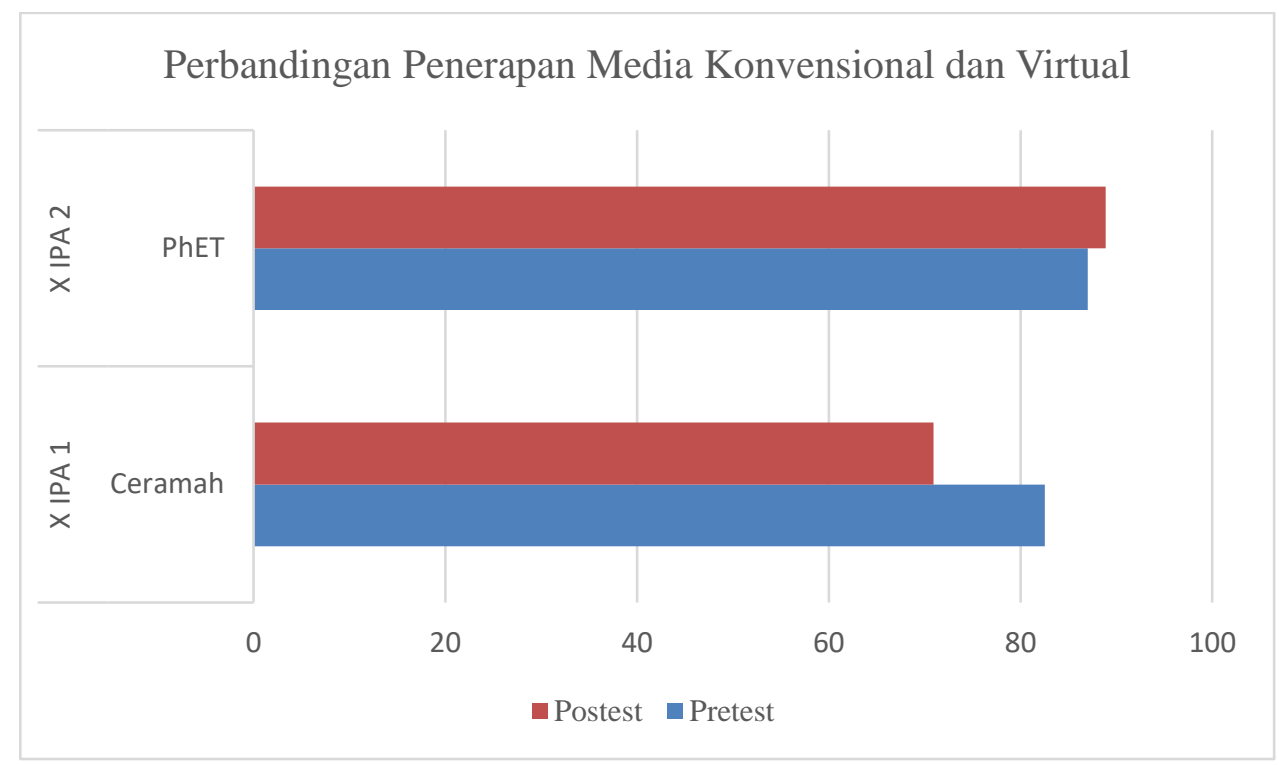

Gambar 2. Grafik perkembangan peningkatan berfikir sains siswa dari pre-test ke posttest

Dari Tabel 1 dan Gambar 2 dapat diketahui bahwa penggunaan sistem metode ceramah ternyata peningkatannya semakin menurun, sedangkan penggunaan media virtual (PhET Simulation) mengalami peningkatan. Penyebab nilai pre-test ke post-tes pada kelas X IPA 1 (metode ceramah) menurun dikarenakan siswa kurang memahami konsep secara maksimal dan dan tidak dapat melakukan praktek secara langsung atau menggunakan teknologi, sehingga siswa kurang memahami pembelajaran secara cepat. Dapat disimpulkan X IPA 2 memiliki peningkatan yang lebih besar dibandingkan kelas X IPA 1. Sehingga penggunaan PhET Simulation sangat berpengaruh penting dalam proses keterampilan berfikir sains siswa. PhET Simulation berpangaruh pada peningkatan keterampilan proses sains siswa dikarenakan dalam aplikasi PhET Simulation program yang menyediakan simulasi fenomena fisik berbasis penelitian secara gratis, menyenangkan, interaktif dan bias mengajak siswa untuk belajar dengan cara-cara mengeksplorasi secara langsung. Dengan program ini, siswa bisa lebih nyata mengamati fenomena yang ada sehingga bisa menumbuhkan motivasi lebih tinggi untuk belajar. Hal ini sesuai dengan pernyataan dari Suryani (2015) dalam penelitiannya mengatakan bahwasannya penggunaan media yang bersifat 3D dan memanfaatkan teknologi serta aplikasi dapat meningkatkan motivasi dan ketampilan berfikir sains siswa.

Pada penelitian kemampuan berfikir kreatif siswa yang diajar dengan menggunakan media yang mengandung unsur 3D lebih baik dari kemampuan berfikir kreatif siswa yang diajar dengan menggunakan metode ceramah saja (Fatih, 2016).

Menurut Soekamto (dalam trianti, 2009) hal tersebut sesuai dengan teori yang menyatakan bahwa model dan metode pembelajaran merupakan kerangka konseptual yang melukiskan 
posedur yang sistematis dalam mengorganisasikan pengalaman belajar untuk mencapai tujuan belajar tertentu, dan berfungsi sebagai pedoman bagi perancang pembelajaran dan pengajar dalam merencanakan aktivitas belajar mengajar. Oleh karena itu, guru sebagai pengajar harus mampu memahami model dan metode pembelajaran dengan baik agar pembelajaran dapat terlaksana dengan efektif serta tujuan yang akan dicapai.

\section{KESIPULAN DAN SARAN}

Penelitian mengenai perbandingan pembelajaran dengan menggunakan media dan metode yang berbeda dengan kelas yang berbeda karena fakta lapagan yang menunjukkan pembelajaran fisika di sekolah masih berpusat pada guru atau bersifat teacher-centered dan masih belum memanfaatkan teknologi aplikasi secara maksimal, sehingga siswa mengalam peningkatan yang sedikit sekali dalam keterampilan berfikir sains. Kesimpulan dalam penelitian ini adalah siswa yang mendapatkan pembelajaran menggunakan model Problem Based Instruction dengan media Phet Simulation mengalami peningkatan keterampilan proses sains siswa dalam melakukan praktikum atau pembelajaran. Dengan demikian, maka penggunaan media virtual mampu menjadi alternatif proses pembelajaran dalam meningkatkan keterampilan proses sains siswa.

\section{DAFTAR PUSTAKA}

Amri, Sofan \& Iif Khoiru Ahmadi. (2010). Proses Pembelajaran Inovatif dan Kreatif Dalam
Kelas, Jakarta: Prestasi Pustakaraya.

Anderson dan Krathwohl. (2001). A Taxonomy for Learning, Teaching, and Assessing (A Revision of Bloom's Taxonomy of Educational Objectives) Abridge Edition. New York: David McKay Company.

Azhar, Arsyad. (2011). Media Pembelajaran. Jakarta: Raja Grafindo Persada.

Fatih, Ahmad. 2016. Implementasi Model Pembelajaran Jigsaw Disertai Refleksi Diri Untuk Meningkatkan Kemampuan Berfikir Kreatif Siswa Pada Pokok Bahasan Gerak Parabola. Semarang : Uniersitas Negeri Senarang

Mundilarto. (2010). Penilaian Hasil Belajar Fisika. Yogyakarta : P2IS UNY.

Nana Sudjana dan Ahmad Rivai. (2009). Media Pengajaran. Bandung: Sinar Baru Algensindo.

Oemar, Hamalik. (2005). Proses Belajar Mengajar. Bandung: Bumi Aksara.

Slameto. (2010). Belajar dan FaktorFaktor yang Mempengaruhinya. Rineka Cipta. Jakarta

Suryani, Ajeng . (2015). Pengembangan Multimedia Komputer untuk Konsep Gerak Lurus Siswa Menengah Pertama. Jurnal Pendidikan, Universitas Pendidikan Indonesia

Trianto. 2009. Mendesain Model Pembelajaran Inofatif Progresif. Jakarta : Cerdas Kencana Prenada Media 